
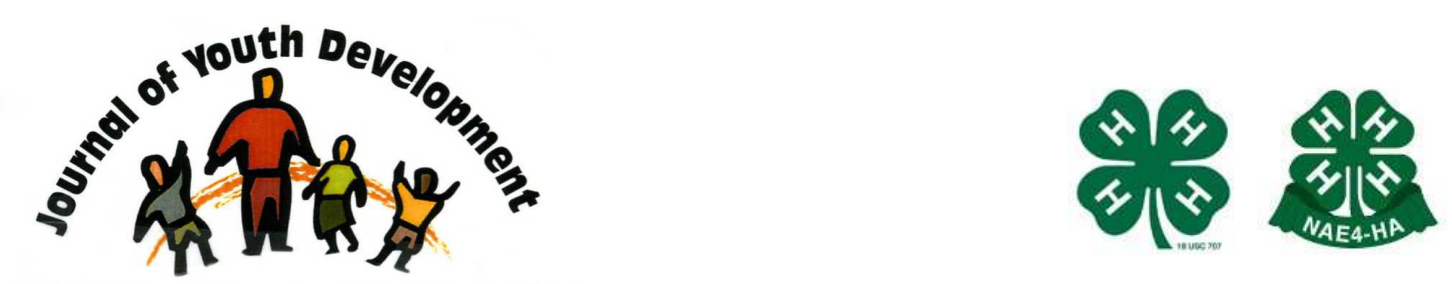

Bridging Research \& Practice

\title{
Factors Influencing 4-H Club Enrollment and Retention in Georgia
}

\author{
Amber B. Defore \\ University of Georgia Extension Service \\ Woodbine, GA \\ adefore@uga.edu
}

Nicholas E. Fuhrman

Dept. of Ag Leadership, Education \& Communication

University of Georgia

Athens, GA

fuhrman@uga.edu

Jason B. Peake

Dept. of Ag Leadership, Education \& Communication

University of Georgia

Tifton, GA

jpeake@uga.edu

Dennis W. Duncan

Dept. of Ag Leadership, Education \& Communication

University of Georgia

Athens, GA

dwd@uga.edu 


\title{
JOURNAL OF YOUTH DEVELOPMENT \\ bridging research and practice

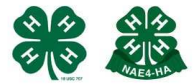

Volume 6, Number 2, Summer 2011

Article 110602FA005

\section{Factors Influencing 4-H Club Enrollment and Retention in Georgia}

Amber B. Defore, Nicholas E. Fuhrman, Jason B. Peake and Dennis W. Duncan University of Georgia

\begin{abstract}
Middle school aged $4-\mathrm{H}$ member participation is on the decline across the nation. Research has identified reasons for declining 4-H club participation, including conflicting time commitments (with school and community activities) and opinions that the program was boring or for little kids. This study sought to gain a clearer understanding of why 4-H member involvement in Camden County, Georgia has steadily declined in recent years. The most prevalent reason listed for leaving the Camden County 4-H program was that the 4- $\mathrm{H}$ meeting conflicted with school and community activities. Other reasons listed included wanting to be with friends in a relaxed setting, not liking the activities and lessons at the special interest club meetings, and not feeling welcome in the 4-H club meetings. The 4- $\mathrm{H}$ members who continued with the program had $100 \%$ parental involvement - the number one indicator of continued $4-\mathrm{H}$ participation.
\end{abstract}

\section{Introduction and Literature Review}

\section{Why do 4-H Members Drop Out?}

Recruiting youth in 4-H programs is a priority for youth development professionals. From a youth development standpoint, retaining youth is even more important. There are a number of factors influencing declining rates of youth involvement in 4-H clubs. Previous studies have identified reasons youth drop out of 4-H clubs, including: not understanding the 4-H program, not feeling welcome, conflicting time commitments, opinions that the program was boring or for younger youth, not having the financial ability to pay for some of the programs, an inability for parental involvement such as transportation, a lack of assistance with their project, and project clubs not meeting enough or having appropriate activities (Astroth, 1985; Borden, Perkins, Villarruel, \& Stone, 2005; Digby \& Ferrari, 2005a; Ritchie \& Resler, 1993; Weiss, Little, \& Bouffard, 2005). Still other youth drop out of 4-H and other youth development programs because they are growing developmentally, gaining feelings of independence, and wish to 
demonstrate such independence by removing themselves from programs typically associated with younger audiences (Heinsohn \& Lewis, 1995).

\section{What Keeps 4-H Members Enrolled?}

With an increase in programs offered by the school system and community, students must make decisions about 4-H participation. Often county-level 4-H programs become entirely after school-based programs once the 4-H members enter middle school (sixth grade) (Georgia 4-H Junior Task Force, 2000). Likely reasons for deciding to continue to participate in 4-H clubs in middle school include youth satisfaction with what the program offers and with what they get out of it. Factors that keep 4-H'ers most satisfied with 4-H clubs include: high quality 4-H club meetings, high levels of responsibility, high commitment, positive parental involvement and support, a positive experience with competition, opportunities to work with younger members, gender (girls more satisfied than boys), safe environment, feeling of belonging, time with friends, learning new things and high participation in 4-H activities (Digby \& Ferrari, 2005a; Ferrari \& Turner, 2006; Norland \& Bennett, 1993). They also found that youth were more satisfied with the 4-H program overall when they had the "opportunity to participate in older member activities, positive experiences with competition, and participation in club, county, state, and national activities" (Norland \& Bennett, 1993, Findings section, para. 2).

Support and involvement from parents and adult volunteer leaders during activities and club meetings also influence the likelihood of 4-H members continued involvement (Hartley, 1983; Ladewig \& Thomas, 1987). Ferrari and Turner (2006) found that youth joined and participated in youth programs as a result of caring adults, homework assistance, a positive physical and psychosocial environment, program opportunities, and a fun atmosphere where character and life skills could be developed in the company of friends. If $4-\mathrm{H}$ members completed a project and received recognition, they are also more likely to feel positive about the program, to reenroll and continue their participation (Hartley, 1983; Radhakrishna, Everhart, \& Sinasky, 2006).

\section{What Retains 4-H Members Over Time?}

Once a youth organization finds the "hook" to attract youth to join, it must develop strategies to have continued interest in the program. After all, teens are voluntarily participating in the programs. Flexibility in activities and schedules is one way to maintain interest and retain youth (Heinsohn \& Lewis, 1995). Others suggest increasing the likelihood of youth retention involves encouraging participation of first year club members in 4-H activities, using personal and tangible recognition frequently, designing activities to meet the needs and expectations of $4-\mathrm{H}$ members, and planning 4-H activities to encourage whole family participation (Hartley, 1983). It is also important for teen members to feel a sense of ownership and belonging and to be given leadership roles by sharing their knowledge and experiences (Ladewig \& Thomas, 1987; Norland \& Bennett, 1993; Ritchie \& Resler, 1993). A mentoring system with older members assisting younger or first year members can also help retention rates (Astroth, 1985; Harder et al, 2005; Norland \& Bennett, 1993).

\section{Local Situation: Camden County, Georgia}

Retaining active 4-H members beyond the fifth grade is a challenge in Camden County, Georgia. During the 2005-2006 school year in Camden County, Georgia, the total enrollment in fifth grade $4-\mathrm{H}$ was 547 students. Of the total enrollment, 100 were involved in at least one activity or event outside of the in school club meeting. In the following 2006-2007 school year, only 40 of the 100 formerly active fifth graders reenrolled in $4-\mathrm{H}$. Only 17 active $4-\mathrm{H}$ members from the previous year reenrolled in the seventh grade. While Camden County had approximately 698 sixth graders enrolled in the 2006-2007 school year, only 48 of these sixth graders were active 
in 4-H (State of Georgia Department of Education, Governor's Office of Student Achievement, 2007).

The reenrollment numbers were even lower for the fifth graders that were active in the 2007 4-H year. During the 2006-2007 school year in Camden County, the total enrollment in fifth grade $4-\mathrm{H}$ was 678 students. Of the total enrollment, 115 were involved in at least one activity or event outside of the in school club meeting. In the following 2007-2008 school year, only 29 of the 115 formerly active fifth graders re-enrolled and became an active 4- $\mathrm{H}$ member in the sixth grade. Of these only 14 active $4-\mathrm{H}$ members from the previous year continued in the seventh grade. While Camden County had approximately 737 sixth graders enrolled in the 2007-2008 school year, only 39 of these sixth graders were active in 4-H their sixth grade year (State of Georgia Department of Education, Governor's Office of Student Achievement, 2008). Given these trends, the purpose of this study was to determine contributing factors and possible remedies for the decline in the enrollment and retention of middle school $\left(6^{\text {th }}-8^{\text {th }}\right.$ grade) youth in the Camden County, Georgia 4-H club program.

\section{Objectives}

The objectives of this study were to:

1. Determine the rate of and influences on the reduction in participation in 4-H programs among $6^{\text {th }}-8^{\text {th }}$ grade $4-\mathrm{H}$ members who were formally active in $4-\mathrm{H}$ in the fifth grade;

2. Determine if participation in project achievement, club meetings, judging events, special interest clubs, summer fun trips and/or camp relates to continued participation in 4- $\mathrm{H}$;

3. Determine the reasons why active $4-\mathrm{H}$ members continue to participate in 4- $\mathrm{H}$; and

4. Determine what recruitment and retention efforts should be offered to provide a more attractive $4-\mathrm{H}$ program to sixth grade Cloverleaf and Junior $\left(7^{\text {th }}-8^{\text {th }}\right.$ grade) $4-\mathrm{H}^{\prime}$ ers.

\section{Methods}

The study population consisted of "active" 4-H members from the 2006 4-H year (2005-2006) and the $20074-\mathrm{H}$ year (2006-2007). The youth included in this audience were determined from information retrieved from county-reported information on the Georgia Cooperative Extension 4-H Enrollment Database. The term "active member" is defined as an individual that is involved in activities outside of monthly club meetings including project achievement, judging events, special interest clubs, summer fun trips and/or summer camp.

\section{Part One: Trends in Secondary Data}

The research design consisted of a two part study. Part one was an ex post facto study analyzing information in the 4-H Enrollment Database for Camden County from the 2006 and 2007 4-H years. The secondary data allowed the researchers to identify trends in participation in 4-H activities and determine if a relationship existed between participation and continued enrollment in 4-H. Part one also examined sixth and seventh grade 4- $\mathrm{H}$ members who began 4-H during their fifth grade year to determine if past participation increased their likelihood to remain involved in $4-\mathrm{H}$.

The population for this ex post facto study included 100 active fifth grade 4- $\mathrm{H}$ members in the 2006 4- $\mathrm{H}$ year and 115 active fifth grade 4- $\mathrm{H}$ members in the 2007 4- $\mathrm{H}$ year. Within the Enrollment Database, these 4-H members were categorized into:

a) $4-\mathrm{H}$ members that were active in the fifth grade that reenrolled in $4-\mathrm{H}$ in the sixth grade, 
b) $4-\mathrm{H}$ members that were active in the fifth grade that did not reenroll in $4-\mathrm{H}$ in the sixth grade,

c) 4- $\mathrm{H}$ members that were not actively involved in 4-H until the sixth grade,

d) 4-H members that were active sixth grade participants that reenrolled,

e) 4- $\mathrm{H}$ members that were active sixth grade participants that did not reenroll,

f) 4-H members that were active fifth grade participants that skipped a year and reenrolled as a seventh grade $4-\mathrm{H}$ member, and

g) $4-\mathrm{H}$ members that were not actively involved in $4-\mathrm{H}$ until the seventh grade.

Search functions within the database were used to identify and select 4- $\mathrm{H}$ members meeting these criteria.

\section{Part Two: Questionnaire}

Part two was a needs assessment questionnaire distributed to 4-H members (with parental permission) who were actively involved in 4- $\mathrm{H}$ during their fifth grade years for the 2006 and $20074-\mathrm{H}$ year and reenrolled in their sixth grade year. The questionnaire was used to determine the reasons 4-H members did or did not reenroll in the 4-H program. The questionnaire also asked youth to share their thoughts on programs and activities that should and should not be offered.

The sample population for the questionnaire was self selected by the participants reenrolling in 4- $\mathrm{H}$ in their sixth grade year after being active in at least one after school activity or event in their fifth grade year. Sixth graders that were new to being actively involved in the 4-H program were also included in the sample.

The questionnaire was peer reviewed by Camden County Cooperative Extension and 4-H staff members, other 4-H staff in the district, and the Camden County 4-H advisory board for face and content validity. The questionnaire was pilot tested in the summer of 2009. It was mailed to 52 possible survey participants, resulting in a $23 \%(n=12)$ response rate. The researchers recognize that a sample size of 12 is low for calculating Cronbach's alpha so multiple follow ups with non-respondents were used to try to boost the number of respondents for the pilot test. The maximum number of respondents that could be achieved was 12. Responses were compiled and entered into SPSS 14.0 where reliability (Cronbach's alpha) was calculated for the scales on the instrument. Internal consistencies of all instrument constructs were at least $\mathrm{a}=0.85$, indicating acceptable reliability.

Following the pilot test, the questionnaire was mailed to the active sixth grade 4- $\mathrm{H}$ members from the 2007 and $20084-\mathrm{H}$ years $(\mathrm{N}=115)$ with a letter of description, a letter requesting parental consent, a letter requesting youth assent, and a pre-addressed stamped envelope. Procedures outlined by Dillman (2000) were followed in an attempt to maximize response rates and reduce non-response error. After two follow-up contacts, 23 responses to the questionnaire were collected.

\section{Data Analysis}

Descriptive statistics (frequencies and percentages) were used to summarize the secondary data in the ex post facto study and the quantitative responses to the questionnaire. Responses to open-ended questions on the questionnaire were summarized using domain analysis, including open-coding and color coding procedures (Spradley, 1980). 


\section{Findings}

\section{Objective \#1: Rate of and influences on reductions in 4-H club participation:}

Gender.

The gender of the groups that were not retained for both years was 57 males ( $26.5 \%$ of total) and 83 females (39\% of total). Comparing male and female $4-\mathrm{H}$ member retention over the two years revealed that $65 \%$ of both male and female members dropped out. Therefore, gender had minimal influence on rate of leaving the $4-\mathrm{H}$ club.

\section{Retention.}

There was a substantial decline in the number of members returning that were previously active in the 4-H program (Table 1$)$. In the $2005-2006$ year, $57 \%(n=57)$ of the formally active fifth graders did not reenroll in $4-\mathrm{H}$ for their sixth grade year. Of the 40 returning members $(40 \%), 25(63 \%)$ did not reenroll for their seventh grade year. From the fifth graders that were active in the $2006-2007$ year, 83 members (72\%) did not return. Of the 29 members that did reenroll in $4-\mathrm{H}$ for their sixth grade year, 15 members (52\%) did not reenroll their seventh grade year. With the yearly demonstration, there is a marked decline in participation every year with a specific emphasis in the $2007-2008$ year with $63 \%$ of the first group of fifth graders and $72 \%$ of the second group not returning to the $4-\mathrm{H}$ program after being active in the previous year. It is unknown what contributed to the decline in this specific year.

Table 1

4-H Club Participation by Grade Level $(N=53)$

\begin{tabular}{|l|c|c|c|}
\hline Grade Level & $\boldsymbol{f}$ & \% of Total in Category & Rate of Decline (\%) \\
\hline Active in $5^{\text {th }}$ Grade & 23 & 100 & 0 \\
\hline Active in $6^{\text {th }}$ Grade & 21 & 91 & 9 \\
\hline Active in $7^{\text {th }}$ Grade & 17 & 74 & 19 \\
\hline Active in $8^{\text {th }}$ Grade & 14 & 61 & 18 \\
\hline Active in $9^{\text {th }}$ Grade & 8 & 35 & 43 \\
\hline
\end{tabular}

Reasons for no longer participating in the 4-H club.

The most prevalent reason listed for leaving the 4-H program was that the 4- $\mathrm{H}$ meeting conflicted with school and community activities (30\%). Other reasons listed included wanting to be with friends in a relaxed setting $(n=5)$, not liking the activities and lessons at the special interest club meetings $(n=5)$, and not feeling welcome in the 4-H club meetings $(n=5)$. The open response questions related to no longer participating yielded themes of "involvement in other activities," "feeling 4-H was just for fifth graders," and "club meetings were boring or not interesting."

Comparisons were also made between the six youth respondents that did not reenroll in 4-H after their sixth grade year and the 17 that did reenroll after their sixth grade year and, in some cases, were retained through the seventh, eighth, and ninth grade years. Compared to youth who were retained, more youth who left the $4-\mathrm{H}$ program indicated reasons for leaving such as that $4-\mathrm{H}$ was boring $(50 \%$ compared to $0 \%)$, there were scheduling conflicts ( $50 \%$ compared to $25 \%$ ), and displeasure with activities in club meetings which resemble formal, structured classroom activities ( $83 \%$ compared to $12 \%$ ). Researchers have found that youth and parents do not want their after school time to be associated with more school (Anderson-Butcher, 2005) and desire less structure and more flexibility (Marcazk, Dworkin, Skuza, \& Beyer, 2006). 
Objective \#2: Participation in specific activities and continued 4-H club participation.

The 4-H members that joined 4-H in 2005 and remained active through their seventh grade year participated in core program activities more than other youth (Tables 2 and 3). The researcher also compared the six respondents who did not reenroll in 4-H after their sixth grade year to the 17 who did reenroll after their sixth grade year and in some cases were retained through the seventh, eighth, and ninth grade years.

Table 2

Number of 4-H Activities by Category and Year for the 2005 - 2006 Active Fifth Grade 4-H Members

\begin{tabular}{|l|c|c|c|c|c|c|}
\hline & \multicolumn{2}{|c|}{$\begin{array}{c}\text { 2005 - 2006 } \\
\text { Fifth Grade }\end{array}$} & \multicolumn{2}{c|}{$\begin{array}{c}\text { 2006 - 2007 } \\
\text { Sixth Grade }\end{array}$} & \multicolumn{2}{c|}{$\begin{array}{c}\text { 2007 - 2008 } \\
\text { Seventh Grade }\end{array}$} \\
\hline & \multicolumn{2}{|c|}{$\mathrm{n}=240$} & \multicolumn{2}{c|}{$\mathrm{n}=142$} & \multicolumn{2}{c|}{$\mathrm{n}=113$} \\
\hline 4-H Categories & $F$ & $\%$ & $f$ & $\%$ & $f$ & $\%$ \\
\hline Core Programs & 102 & 43 & 64 & 45 & 32 & 29 \\
\hline $\begin{array}{l}\text { Judging \& } \\
\text { Competitive } \\
\text { Events }\end{array}$ & 32 & 13 & 33 & 23 & 20 & 18 \\
\hline $\begin{array}{l}\text { Special Interest } \\
\text { Clubs }\end{array}$ & 0 & 0 & 1 & 1 & 9 & 8 \\
\hline $\begin{array}{l}\text { Leadership } \\
\text { Conferences }\end{array}$ & 0 & 0 & 0 & 0 & 4 & 3 \\
\hline Recognition & 45 & 19 & 9 & 6 & 0 & 0 \\
\hline Helping & 0 & 0 & 8 & 6 & 18 & 16 \\
\hline $\begin{array}{l}\text { Fun Trips \& } \\
\text { Events }\end{array}$ & 61 & 25 & 27 & 19 & 30 & 26 \\
\hline Total & 240 & 100 & 142 & 100 & 113 & 100 \\
\hline
\end{tabular}

Note: $\mathrm{n}=$ number of activities, $f=$ number of participants in the category

The 4-H members who continued with the program participated more in district and state activities. The members who dropped out may have left too early to see the benefits of the district and state activities because many are not available until the 4- $\mathrm{H}$ member has reached the seventh grade. 
Table 3

Number of 4-H Activities by Category and Year for the 2006 - 2007 Active Fifth Grade 4-H Members

\begin{tabular}{|l|c|c|c|c|c|c|}
\hline & \multicolumn{2}{|c|}{$\begin{array}{c}2006-2007 \\
\text { Fifth Grade }\end{array}$} & \multicolumn{2}{c|}{$\begin{array}{c}2007-2008 \\
\text { Sixth Grade }\end{array}$} & \multicolumn{2}{c|}{$\begin{array}{c}2008-2009 \\
\text { Seventh Grade }\end{array}$} \\
\hline & \multicolumn{2}{|c|}{$\mathrm{n}=261$} & \multicolumn{2}{c|}{$\mathrm{n}=111$} & \multicolumn{2}{c|}{$\mathrm{n}=55$} \\
\hline 4-H Categories & $F$ & $\%$ & $f$ & $\%$ & $f$ & $\%$ \\
\hline Core Programs & 89 & 34 & 39 & 35 & 21 & 38 \\
\hline $\begin{array}{l}\text { Judging \& } \\
\text { Competitive } \\
\text { Events }\end{array}$ & 81 & 31 & 18 & 16 & 15 & 27 \\
\hline $\begin{array}{l}\text { Special Interest } \\
\text { Clubs }\end{array}$ & 0 & 0 & 12 & 11 & 7 & 13 \\
\hline $\begin{array}{l}\text { Leadership } \\
\text { Conferences }\end{array}$ & 0 & 0 & 0 & 0 & 1 & 2 \\
\hline Recognition & 55 & 21 & 8 & 7 & 2 & 4 \\
\hline Helping & 0 & 0 & 4 & 4 & 9 & 16 \\
\hline $\begin{array}{l}\text { Fun Trips \& } \\
\text { Events }\end{array}$ & 36 & 14 & 30 & 27 & 0 & 0 \\
\hline Total & 261 & 100 & 111 & 100 & 55 & 100 \\
\hline
\end{tabular}

Note: $\mathrm{n}=$ number of activities. $f=$ number of participants in the category

Regardless of whether they remained in 4- $\mathrm{H}$ or dropped out, 4- $\mathrm{H}$ members who began $4-\mathrm{H}$ in the $20064-\mathrm{H}$ year participated in core programs and received similar amounts of recognition. For 4- $\mathrm{H}$ members who began $4-\mathrm{H}$ in the $20074-\mathrm{H}$ year, the members who were retained had higher participation percentages in every category except judging and competitive events (Table 4). Forty-eight percent of the members who left the 4-H program participated in judging and competitive events. Participation in such events may have contributed to their withdrawal from the 4-H club. 
Table 4

Members Retained for 2006 - 2008

Participating in at least One Project from a Given Category

\begin{tabular}{|l|c|c|c|c|c|c|}
\hline & \multicolumn{4}{|c|}{ Retained (n = 15) } & \multicolumn{2}{c|}{ Not Retained (n = 83) } \\
\hline & $\mathbf{2 0 0 6 - 2 0 0 7}$ & \multicolumn{2}{|c|}{$\mathbf{2 0 0 7} \mathbf{- 2 0 0 8}$} & \multicolumn{2}{|c|}{$\mathbf{2 0 0 6 - 2 0 0 7}$} \\
\hline Project Categories & $f$ & $\%$ & $F$ & $\%$ & $f$ & $\%$ \\
\hline Core Programs & 13 & 87 & 11 & 73 & 46 & 55 \\
\hline $\begin{array}{l}\text { Judging \& } \\
\text { Competitive Events }\end{array}$ & 5 & 33 & 3 & 20 & 40 & 48 \\
\hline $\begin{array}{l}\text { Special Interest } \\
\text { Clubs }\end{array}$ & N/A & -- & 2 & 13 & N/A & -- \\
\hline $\begin{array}{l}\text { Leadership } \\
\text { Conference }\end{array}$ & N/A & -- & N/A & -- & N/A & - \\
\hline Recognition & 7 & 47 & 3 & 20 & 33 & 40 \\
\hline Helping & N/A & -- & 1 & 7 & N/A & -- \\
\hline $\begin{array}{l}\text { Extra Fun Trips \& } \\
\text { Events }\end{array}$ & 5 & 33 & 5 & 33 & 15 & 18 \\
\hline
\end{tabular}

The competitive experience may be part of the reason the members not retained decided to not reenroll (Albright, 2008). When analyzing these participation results, one conclusion could be that this study's participants contradict the research by Hartley (1983) and Norland and Bennett (1993) who found that participation contributes to reenrollment. However, when comparing the participation percentages of the group of 4- $\mathrm{H}$ members who were retained for three years to the groups who were retained for only one or two years, the results show that the 4-H members retained the longest participated in more activities overall.

Objective \#3: Reasons for continuing to participate in the 4-H club.

The questionnaire asked youth respondents to share any reason that contributed to their decision to continue participating in 4-H. Of the 53 questionnaires mailed to participants, 23 completed questionnaires were returned ( $43 \%$ response rate). Responses were grouped into similar themes/domains and compared based on frequency of being mentioned (Spradley, 1980). The domain "learning and life skill development" had the most responses, followed by "parental support." Participation in activities as a fifth grader and the S.A.F.E. shooting sports program also led many of the respondents to continue with the 4-H program. 4-H members liked being given responsibility by setting and achieving goals. Additional reasons $4-\mathrm{H}$ members continued to participate in 4- $\mathrm{H}$ were because they felt $4-\mathrm{H}$ was fun, liked learning new things, and enjoyed 4-H events including camp.

Respondents were also asked whether participation in judging events and special interest clubs influenced their decision to continue participating. Neither judging events $(n=16,70 \%)$ nor special interest clubs $(n=19,83 \%)$ influenced their decision to continue participating in 4-H. This could imply that participating in these activities also did not contribute to respondents reenrolling in the following years. 
Differences were found when reasons for continuing with the 4-H program were compared between those who dropped out and those who reenrolled. These included participation in judging events ( $0 \%$ vs. $35 \%$ ), desire to participate in state and district activities (0\% vs. $65 \%)$, wanting to be a teen leader (33\% vs. $71 \%)$, liking the $4-\mathrm{H}$ activities (17\% vs. $88 \%)$, parents being involved in the program (17\% vs. $100 \%)$, motivation to succeed (33\% vs. $71 \%$ ), and the desire to be given additional responsibility (17\% vs. $65 \%)$.

The 4-H members that remained with the program responded often to having their parents involved in the $4-\mathrm{H}$ program. The $4-\mathrm{H}$ members that continued with the program had $100 \%$ parental involvement. Parents are able to be involved in the 4-H program by serving as a leader or coach of a special interest club or judging event, serving as a volunteer at events, or being part of the 4-H advisory board. Norland and Bennett (1993) found that positive parental involvement was a factor that led to more satisfaction with the program by youth.

Program participation was also influenced by a desire to build leadership skills. Club members who continued with the program wanted to be teen leaders, achieve their goals, succeed, and have additional responsibility. Norland and Bennett (1993) noted that 4-H members strive to be given responsibility and leadership roles. Ferrari and Turner (2006) found that among many other factors, development of life skills was a reason that youth participated in youth programs such as $4-\mathrm{H}$.

\section{Objective \#4: Recruitment and retention efforts to enhance participation.}

Marketing in order to acquire new members and recognizing current members is important to the success of a 4-H program. Respondents selected promoting new activities $(n=22,96 \%)$, promoting opportunities to be with friends $(n=21,91 \%)$, and promoting 4-H at open house $(\mathrm{N}=21,91 \%)$ as potential methods of recruitment. In terms of specific recruitment strategies, the recruitment method suggested most by respondents ( $n=19,83 \%)$ was for $4-\mathrm{H}$ leaders to follow up with current members who miss club meetings. 4-H members recruiting their friends was also suggested as an effective recruitment strategy $(n=17,74 \%)$. Digby and Ferrari (2005b) found similar recruitment recommendations.

\section{Promoting the 4-H Program}

Youth respondents were asked to provide recommendations for promoting the 4-H program in their communities. Responses recommended promoting 4-H around the community with posters, in parades, and at local festivals. Another common suggestion for promoting the program was to host 4-H special events such as games, road trips, 4-H $5 \mathrm{~K}$ road races, National 4-H Days, 4-H kayak/canoe trips, and community environmental clean ups.

New activities were also suggested by youth in the form of special interest clubs. Clubs requested included general projects, recycling, music, art, first aid, archery, poultry, and a football team. However, questionnaire results showed that special interest clubs currently had the lowest number of participants. Respondents did not feel that the special interest clubs affected their reasons for continuing with the program. Of the 4-H members that were retained, very few participated in the special interest clubs. This could be because they did not know about the clubs or understand their purpose. 


\section{Conclusions, Implications, and Recommendations}

\section{4-H Club Development}

Four main implications for 4-H programs have emerged from the data; focus on fun, schedule considerations, community based programs, and parental support. These four implications are examined in the following pages.

\section{Focus on fun.}

Camp, special events, and trips were referred to often as reasons for returning and as recommended methods of recruitment. Youth want to have fun and most 4-H members recognize 4-H as fun. Leaders should design programs to incorporate youth desire for leisure and variety over a more traditional, "school-based" approach. Additional work is needed to ensure that 4-H leaders do not only focus on the educational aspects of programs, but also maintain fun as one of the key components of their programs and ensure that fun is purposively included in 4-H activities.

\section{Schedule considerations.}

Former 4-H members were busy or were not satisfied with the 4-H program. One participatory approach to 4-H programming would be to ask youth about their schedules, interests, and ideal times to meet. As youth increase in age so do their opportunities for activities; sports, extracurricular school activities, employment, and dating all increase in importance. As youth obligations in other activities increase with age, 4- $\mathrm{H}$ and other youth development programs will have to adapt their marketing strategies to demonstrate their relevance. $4-\mathrm{H}$ programs must appear more attractive to youth than competing opportunities or adjust meeting schedules to avoid conflicting with these other activities.

\section{Community based programs.}

It is important to determine the interest in and need for special interest clubs and judging events before initiating and promoting new programs. 4-H members indicated individual interest in possible special interest club topics. However participation in previous special interest clubs has been low in Georgia. Given their traditionally higher levels of participation, core programs can be the hook to get youth more involved in 4-H clubs. Once youth are involved in the core programs, leaders should determine youth interest in specific special interest clubs. It is recommended that core programs may be best administrated from the state level and facilitated by the local 4-H program leaders. And that specific special interest clubs be determined by local 4- $\mathrm{H}$ program leaders; administered and facilitated by the local 4- $\mathrm{H}$ leader to ensure that specific needs of local youth are being met by the local program.

\section{Parental support.}

4-H members also recognized that parental support was an important factor in continuing to participate in 4-H. No other single individual has a greater influence on a child's development than their parents; ultimately controlling the youth's schedules, resources, and activities.

Achieving parents' support for the program is critical, and participatory approaches should be implemented. For example, during an introductory 4-H club meeting, facilitate a roundtable discussion with parents concerning their child's 4-H experience. As gate keepers in this process, inviting input from these stakeholders is vital.

\section{Further Data Collection}

More research is needed to further understand the variables influencing 4-H club enrollment and retention. Focus groups with current 4- $\mathrm{H}$ members could help determine changes that 
need to be made to retain more youth in the 4-H program. These focus groups could be made up of the officers of each of the middle and high school clubs in the form of a county council or youth advisory committee. This would provide 4-H members with the leadership and responsibility roles they desired (as found in this study and elsewhere).

Another focus group method could be to follow up with the 4-H members who continued with the program by asking questions about reasons for staying, parental involvement, and propensity of leadership opportunities. Answers to these questions would help 4-H staff determine the most effective methods for retaining $4-\mathrm{H}$ members in the future.

Another option could be to develop and implement more opportunities for middle school 4-H members, especially $6^{\text {th }}$ grade $4-\mathrm{H}^{\prime}$ ers, who dropped out waiting to be eligible for Junior $4-\mathrm{H}$ activities. Since fun and camp trips were given as reasons for returning to the program in following years, more trips that incorporate fun, learning, positive youth-adult partnerships, and overnight residential experiences should be offered.

4-H leaders should increase marketing efforts in schools and communities by encouraging 4-H members to recruit their friends, following up with members who miss meetings, providing information to youth and parents about the benefits of $4-\mathrm{H}$, and participating in more community activities including festivals and parades. These efforts would help remind 4-H members and the community that 4- $\mathrm{H}$ is still available to middle and high school students.

Additional research is needed to determine if focus on fun, schedule considerations, community based programs, or parental support have the greatest effect on youth participation and retention in 4-H programs. Anecdotal evidence suggests that there is no single answer to the question of how to increase 4-H member enrollment and participation. More sophisticated research design models and statistical analysis are needed to isolate the role each variable plays, identify multiple variable interactions, and create a prioritized list of actions that 4- $\mathrm{H}$ leaders can implement to increase youth participation and involvement.

According to the Harvard Family Research Project (Lauver, Little, \& Weiss, 2004) which studied over 40 out-of-school time (OST) programs including Big Brothers/Big Sisters of America and Boys \& Girls Clubs of America, low attendance is the norm in many OST programs for middle and high school youth. This is due to busy schedules and family lives, claims of boredom, or the desire for freedom. Their study also looked into the incentives and barriers to participation and made similar recommendations as this study, including helping youth understand the value of participation, showing families the opportunities associated with participation, matching program goals to participant needs, considering at-risk youth in recruitment efforts, recruiting friends to join together, hiring program staff that can relate to youth, linking academics to an engaging project, and giving high school youth extra opportunities.

In fact, youth often participate in more than one activity and need to have the opportunity to have a variety of options to choose from (Theokas, Lerner, Phelps, \& Lerner, 2006). Youth will often change their mind about what they want to participate in and the youth development program must work to recruit and retain youth by promoting their program and providing options which meet youth needs and desires. The results of this study offer guidance for youth development professionals hoping to enroll and retain youth in educational activities and programs. 


\section{References}

Albright, M.B. (2008). Here today, gone tomorrow: An investigation into why older you leave the 4-H program (Unpublished doctoral dissertation). The Ohio State University, Columbus. Retrieved from http://etd.ohiolink.edu/view.cgi?acc num=osu1227037768

Anderson-Butcher, D. (2005). Recruitment and retention in youth development programming. The Prevention Researcher, 12(2), 3 - 6.

Astroth, K.A. (1985). The challenge of retaining 4-H members. Journal of Extension, 23(3). Retrieved from http://www.joe.org/joe/1985fall.sa4.html

Borden, L.M., Perkins, D.F., Villarruel, F.A. \& Stone, M.R. (2005). To participate or not to participate: That is the question. New Directions of Youth Development, 105, 33-49.

Digby, J. \& Ferrari, T.M. (2005a, October). Motivations and barriers to participation in youth programs. Ohio Buckeye Clover Graham, 8 -9. Retrieved from http://www.ohio4h.org/tferrari/documents/October2005CloverGraham.pdf

Digby, J. \& Ferrari, T.M. (2005b, December). Recruiting and retaining youth in programs. Ohio Buckeye Clover Graham, 6-7. Retrieved from

http://www.ohio4h.org/tferrari/documents/December2005CloverGraham.pdf

Dillman, D.A. (2000). Mail and internet surveys: The tailored design method. New York, NY: John Wiley and Sons.

Ferrari, T.M. \& Turner, C.L. (2006). An exploratory study of adolescents' motivations for joining and continued participation in a 4-H afterschool program. Journal of Extension, 44(4) Article Number 4RIB3. Retrieved from http://www.joe.org/joe/2006august/rb3.php

Georgia 4-H Junior Task Force. (2000). Current Programming Survey Results Summary.

Hartley, R. (1983). Keeping 4-H members. Journal of Extension, 21(4). Retrieved from http://www.joe.org/joe/1983july/a4.php

Harder, A., Lamm, A., Lamm, D., Rose, H., \& Rask, G. (2005). An in-depth look at 4-H enrollment and retention. Journal of Extension, 43(5), Article 5RIB4. Retrieved from http://www.joe.org/joe/2005october/rb4.php

Heinsohn, A.L. \& Lewis, R.B. (1995). Why do teens drop out?: A developmental view. Journal of Extension, 33(1). Retrieved from http://www.joe.org/joe/1995february/comm1.html

Ladewig, H., \& Thomas, J.C. (1987, February 1). Does 4-H make a difference? The 4-H alumni study. (ERIC Document Reproduction Service No. ED282682) Retrieved from ERIC database.

Lauver, S., Little, P.D.M., \& Weiss, H. (2004). Moving beyond the barriers: Attracting and sustaining youth participation in out-of-school time programs. Cambridge, MA: Harvard Family Research Project, 6, $1-16$. 
Marczak, M.S., Dworkin, J., Skuza, J., \& Beyer, J. (2006). What's up? What young teens and parents want from youth programs. New Directions for Youth Development, 112, 45 - 56.

Orland, E. \& Bennet, M.B. (1993). Youth participation. Journal of Extension, 31(1). Retrieved from http://www.joe.org/joe/1993spring/a5.php

Radhakrishna, R.B., Everhart, L., \& Sinasky, M. (2006). Attitudes of 4-H participants about 4-H competitive events. Journal of Extension, 44(6), 6RIB3. Retrieved from http://www.joe.org/joe/2006december/rb3.shtml.

Ritchie, R.M. \& Resler, K.M. (1993). Why youth drop out of 4-H. Journal of Extension, 31(1). Retrieved from http://www.joe.org/joe/1993spring/rb3.php

Spradley, J.P. (1980). Participant observation. New York, NY: Holt, Reinehart, and Winston.

State of Georgia Department of Education Governors Office of Student Achievement. (2007). 2006 - 2007 Report card Camden county: student and school demographics, pp. 21. Retrieved from http://public.doe.k12.ga.us/Reports/2007/620/ALL/Reportcard/PDF/OSA-K12-620-ALL.pdf

State of Georgia Department of Education Governors Office of Student Achievement. (2008). 2007 - 2008 Report card Camden county: student and school demographics, 21. Retrieved from http://public.doe.k12.ga.us/Reports/2008/620/ALL/Reportcard/PDF/OSA-K12-620-ALL.pdf

Theokas, C., Lerner, J. V., Phelps, E., \& Lerner, R. M. (2006). Cacophony and change in youth after school activities: Findings from the 4-H study of positive youth development. Journal of Youth Development, 1(1), 0601FA001. Retrieved from http://s3.memberclicks.com/site/nae4a/JYD 060101final.pdf.

Weiss, H.B., Little, P.M.D., \& Bouffard, S.M. (2005). More than just being there: Balancing the participation equation. New Directions of Youth Development, (105), 15-31.

(C) Copyright of Journal of Youth Development $\sim$ Bridging Research and Practice. Content may not be copied or emailed to multiple sites or posted to a listserv without copyright holder's express written permission. However, users may print, download or email articles for individual use. 